\title{
On Protecting Farmers' New Varieties: New Approaches to Rights on Collective Innovations in Plant Genetic Resources
}

\author{
Rene Salazar, Niels P. Louwaars, and Bert Visser
}

2033 K Street, NW, Washington, DC 20006-1002 USA • Tel.: +1-202-862-5600 • Fax: +1-202-467-4439 ifpri@cgiar.org www.ifpri.org

NOTICE: CAPRi Working Papers contain preliminary material and research results, and are circulated prior to a full peer review in order to stimulate discussion and critical comment. It is expected that most CAPRi Working Papers will eventually be published in some other form, and that their content may also be revised.

Copyright 2005, International Food Policy Research Institute. All rights reserved. Sections of this material may be reproduced for personal and not-for-profit use without the express written permission of but with acknowledgment to IFPRI. To reproduce the material contained herein for profit or commercial use requires express written permission. To obtain permission, contact the Communications Division at ifpri-copyright@cgiar.org 


\begin{abstract}
Current farmers' breeding goes beyond the gradual selection in landraces, and includes development and maintenance of major new farmers' varieties that are rather uniform, in particular in South-East Asia. Modern varieties developed in the formal sector have simply replaced landraces as the source of diversity, but have not abolished farmers' breeding practices. Interpretations of the new international agreements on plant genetic resources should protect the development of modern farmers' varieties. However, ensuring recognition of collective innovation, allowing access to relevant germplasm sources for farmers' breeding activities, keeping materials freely available, and arranging for effective benefit sharing, all form major challenges. This paper proposes a new protective measure: namely "origin recognition rights."
\end{abstract}

Keywords: Farmers' varieties; collective rights; origin recognition; declaration of origin; South-East Asia 


\section{TABLE OF CONTENTS}

1. Introduction 1

2. Farmers' Practices 3

3. The Impact of Participatory Plant Breeding on the Development of New Farmers' Varieties

4. Genetic Background of Modern Farmers' Varieties 9

5. New Farmers' Varieties in the IPR Environment 11

6. Alternative Options for the Protection of the Products of Farmers' Breeding 23

$\begin{array}{ll}\text { 7. Conclusion } & 31\end{array}$

$\begin{array}{ll}\text { References } & 32\end{array}$ 


\title{
PROTECTING FARMERS' NEW VARIETIES: NEW APPROACHES TO RIGHTS ON COLLECTIVE INNOVATIONS IN PLANT GENETIC RESOURCES
}

\author{
Rene Salazar, ${ }^{1}$ Niels P. Louwaars, ${ }^{2}$ and Bert Visser ${ }^{3}$
}

\section{INTRODUCTION}

$\mathrm{FAO}^{4}$ defines a landrace as an early, cultivated form of a crop species, evolved from a wild population, and generally composed of a heterogeneous mixture of genotypes. Landraces form a major component of farmers' plant genetic resources (PGR) included in genebank collections, and this material provides the backbone of agriculture and plant breeding today. In addition, landraces are often rooted in local communities' culture and are identified as part of cultural heritage. Many concerns regarding the need for protection of farmers' PGR relate in general terms to such landraces without providing much detail on the type of germplasm actually referred to. This focus on traditional landraces may be understandable as often such concerns stem from the genebank community and non-specialist development organisations, which are most familiar with landraces. However, landraces as defined above do not form the only and perhaps not even the most important germplasm maintained by today's farmers, who continue to develop new farmers' varieties. These new farmers' varieties are based on diverse sources, and build on landraces and local varieties from farmers' communities as well as on germplasm from the public and private sector. This paper discusses the needs

\footnotetext{
${ }^{1}$ Pedigrea Foundation, Manila, the Philippines

${ }^{2}$ Centre for Genetic Resources, the Netherlands

${ }^{3}$ Corresponding Author. Pedigrea Foundation, Manila, the Philippines and Centre for Genetic Resources, the Netherlands

${ }^{4}$ http://www.fao.org/biotech/
} 
and options for protection of modern farmers' varieties, and the specific features of modern farmers' varieties complicating such options.

In general, landraces continue to be cultivated in marginal production areas and in subsistence systems. In high potential areas across the world, to a large extent most landraces have long been replaced by modern cultivars as production systems moved from subsistence cultivation to intensive and market-oriented systems. Landraces, generally of long duration and selected for stability under low-external-input conditions and diverse and adverse environments, could often not compete with new high-yielding varieties that were bred for intensive production systems and allow for more growing cycles per year (FAO 1998). Thus, farmers started to grow such new high-yielding cultivars available to them on the market or from public or private sources.

However, even under market-oriented and intensive production systems, farmers continue to create their own varieties. Modern varieties have simply replaced landraces as the source of diversity, but have not abolished farmers' breeding. The reason for this development is that farmers often recognize the attractive features of modern varieties, including high yields and novel resistances, but also identify various characters that are not appreciated, especially regarding taste, processing qualities, and resilience under less optimal growing conditions. This is especially evident in South-East Asia where rice is the major staple crop, but also in other regions and for other crops. Experiences described here deal mostly but not exclusively with practices found in South-East Asia.

This paper first presents description and analysis of current farmers' practices in regions exposed to germplasm developed by the public and private sector (section 2, 3 and 4), followed by a discussion of the legal background against which such practices are 
undertaken (section 5). It concludes with a proposal for a more appropriate regulatory system to protect such practices given their contribution to the conservation and development of genetic resources (section 6).

\section{FARMERS' PRACTICES}

We first present some examples of farmers' practices that use modern varieties for further breeding and selection.

- IR36 represents one of IRRI's (International Rice Research Institute) most successful varieties released over the last decades. This variety is grown over large acreages. Possibly more than 50 phenotypically different IR36 rice types based on farmers' experimentation have been included in the IRRI gene bank (pers. comm. M. Jackson), pointing at farmers' breeding based on germplasm provided by the formal ${ }^{5}$ breeding sector.

- Eight years ago the Philippine Seed Board certified the farmers' variety "Bordagol," a very popular variety that was spreading throughout the country. The farmer who selected this variety claimed that he selected Bordagol as an "offtype" from an IR36 rice field. Apparently, the Philippine Seed Board found the level of distinctness, uniformity and stability sufficient for such registration.

- In the island province of Bohol in the central Philippines, the local population prefers rice grains with a red colour, as this characteristic is associated with a better quality and greater satisfaction after the meal. Over a few years, many Philippine Seed Board-released rice varieties available in the island gave rise to new phenotypes with red grains. Four well-known phenotypes are Red IR36, Red IR66, Red 77, and RC18 selection. Molecular studies comparing these red types with the original varieties showed that these varieties descended from the original formal sector varieties and had incorporated the preferred red pericarp trait. The studies concluded that this trait most probably resulted from introgression of

\footnotetext{
${ }^{5}$ In this contribution the term formal sector refers to both public sector and private sector.
} 
genes from traditional red rice varieties exhibiting this trait in the newly released Seed Board varieties. Such local red rice varieties were indeed grown in the area in which the modern red grain types originated. Furthermore, the studies indicated that farmers had a keen eye for identifying this preferred trait in the field grown with newly released formal sector varieties. Thus, farmers actively selected within their stocks of IRRI varieties for a preferred additional trait (Bertuso et al. 2005).

- A study of the popular local rice variety "Tai Nguyen" in southern Vietnam showed that economic reforms created a large demand for this aromatic rice variety in urban centers, in particular in Ho Chi Minh City. "Tai Nguyen" is now cultivated in high-external-input systems, unlike in the past, and can be found over large distances across the Mekong Delta. Comparison between the "Tai Nguyen" varieties from gene bank stocks collected 15 years ago with those that are presently cultivated and comparison between samples from different geographic origins within the Mekong Delta surprisingly showed that no phenotypic and molecular differences had emerged in the "Tai Nguyen" variety and that farmers readily and accurately identified off-types (Tin et al., 2001; Tin et al., submitted), exemplifying that farmers are able to accurately maintain a preferred variety.

- It is estimated that approximately 20 percent of rice varieties cultivated in an area of around 5,000 hectares under high-external-input conditions in North Cotabato Province in Mindanao, in the southern Philippines, constitute farmers' varieties. These varieties are distinct and exhibit a fairly high degree of uniformity and stability compared to landraces; and they show traits that are desirable under this production system, such as medium or short stature, short or medium term duration, and non-photosensitivity. In North Cotabato, the participatory plant breeding project PEDIGREA ${ }^{6}$ collaborates with farmers who used to practice local crosses before the start of the project, and who applied their expertise to

\footnotetext{
${ }^{6}$ www.pedigrea.org
} 
crosses between modern varieties distributed by Philrice or IRRI and preferred local varieties.

- In Nepal, participatory plant breeding resulted in new rice varieties for highaltitude areas. One of the most adopted varieties, Machhapuchre-3, that was based on farmers' selection from a segregating F3 population, performed much better than the products from centralized breeding (Joshi et al., 2001) and spread over large areas. All selection for this variety was done in two villages in the same valley, indicating that farmers' varieties may spread over wide areas.

For other staple crops, similar observations have been made and recorded.

- Ceccarelli et al. (2001), who have a long track-record in barley breeding, compared farmer selection strategies in Syria and other countries with formal breeding selection strategies and identified substantial differences between the barley lines selected by formal breeders on-station and by farmer-breeders in their fields. Their work demonstrated that it is possible to organize a plant breeding programme so that farmers become major actors in the selection of new cultivars.

- Toledo Machado and Fermandes (2001) reported about a maize improvement project in the State of Rio de Janeiro, Brazil, showcasing collaborative contributions from the formal sector and farming communities based on a local maize variety as starting material. Six cycles of mass selection in the agricultural community of Sol da Manhã resulted in an upgraded local variety characterized by low nitrogen use, rendering the variety highly attractive for small-scale farmers.

- Hardon (pers. comm.) referred to the presence of small plots of new commercial maize varieties in small-scale farmer fields in East Java deliberately planted amidst local varieties to allow random introgression of genetic information into farmers' own varieties with the purpose to enrich and improve such varieties. Such strategy was preferred to straight adoption of the new commercial varieties. 
- Louette (1999) described major differences among maize farmers in the state of Jalisco on the Pacific Coast of Mexico. Some farmers select seeds almost exclusively from their own harvests, whereas farmers who do not produce enough seed for the next season buy all their seeds. The most interesting group of farmers use their own seed lots in addition to seed acquired in the community or introduced from other regions, and thus experiment with new varieties. In the case of maize, continuous introduction of new varieties leads to extensive geneflow within and between varieties. At the same time, these farmers are well able to maintain all the typical characteristics of their preferred local varieties, like in the case of the "Tai Nguyen" rice variety in Vietnam. The assumption that traditional systems are closed with respect to geneflow is clearly contradicted.

The farmers' varieties of the examples above often emerged as farmers' selections from modern and traditional cultivars in market-oriented production systems. Selection and the emergence of new farmers' varieties is occurring with as well as without external intervention or support. Farmers' practices may or may not include crossing and conscious creation of new genotypes, or rely on natural introgression events keenly identified and followed by selection. Once a preferred variety has been established farmers are well able to maintain its typical characters, although generally farmers' varieties are deliberately maintained more heterogeneous than private sector varieties, in order to overcome the vagaries of environmental conditions. These farmers' varieties are well able to spread over a large area. 


\section{THE IMPACT OF PARTICIPATORY PLANT BREEDING ON THE DEVELOPMENT OF NEW FARMERS' VARIETIES}

Participatory Plant Breeding (PPB) is a container term encompassing various

forms of collaboration between farmers and public sector breeders (Sperling et al. 2001).

PPB may range from programs in which farmers test advanced stable or near-stable lines

produced at breeding stations, to programs in which farmers formulate their own

breeding objectives and for which project implementation is supported by public

institutions and/or NGOs. Major support from the formal sector involves suitable

germplasm and breeding expertise. PPB has the potential of exponentially increasing the

role of farmers in producing new cultivars as described above and of substantially

enlarging the number of new farmers' varieties being developed. This is particularly

evident in those versions of PPB in which farmers take the leading role and the public

sector acts as a support base, since available capacity in the public sector becomes less of

a bottle-neck.

Again, a number of experiences exemplifying the effects of PPB concern rice.

- The "MASIPAG" rice plant breeding programme in the Philippines that released segregating lines to rice farmers in the country has produced three popular varieties in three provinces in the southern Philippines alone. Varieties resulting from PPB are cultivated in more than half of the area planted to rice in one district in North Cotabato province (Conserve, 2001).

- In the Mekong Delta of Vietnam the Community Biodiversity Development and Conservation programme introduced decentralized plant breeding resulting in 37 seed clubs organising more than 1000 farmers, who select their own varieties.

- In Laos, the participatory rice breeding project BUCAP is currently conducting productivity trials of more than 30 stable PPB lines (originating from approximately 30 different crosses). 
- The PEDIGREA project, now in its third year, has been organising and enhancing farmers' capacity to make crosses and perform subsequent selection. Cambodian farmers working with the NGO Srer Khmer are currently conducting productivity trials on 11 stable lines. On the island of Java, PEDIGREA's partner organisation Field Indonesia is facilitating farmers' selection from 84 breeding lines obtained from the Indonesian Rice Research Institute in Sukamandi, including 56 segregating populations $(\mathrm{F} 2-\mathrm{F} 4)$. This project has currently trained 225 farmers of 11 communities in Indramayu district.

For other crops, related experiences have also been documented. Toledo Machado and Fernandes (2001) and Ceccarelli et al. (2001) show how farmers have produced new maize and barley varieties, making use of traditional and modern germplasm in the framework of a partnership between farming communities and the public sector. In addition to enhancing farmers' breeding capabilities in rice, the PEDIGREA project attempts to contribute to the genetic diversity conservation of vegetables.

In many cases, PPB links farmers with formal plant breeders and includes the use of germplasm obtained from the public sector. This set-up intends to make full use of the comparative advantages of the two systems of plant breeding. Access to PGR, and often pre-breeding efforts ${ }^{7}$ and crossings, are provided by plant breeding institutions and genebanks. This increases farmers' access to the PGR collections and breeding populations that such institutes maintain, and fosters the ability to learn and adapt breeding techniques and strategies adopted in institutional plant breeding. In addition, PPB helps to ensure that breeding objectives meet farmers' real preferences and growing conditions, and that varieties are selected and developed accordingly in farmers' fields.

\footnotetext{
${ }^{7}$ The term pre-breeding is used here to indicate the introduction of desired traits from various sources in the genetic background of one or more cultivars.
} 
Since PPB is now increasingly based on the Farmers Field School approach developed in the framework of Integrated Pest Management, it also renders it a much more costeffective strategy. The organisations promoting PPB through this approach have started to move from community to community.

For these reasons PPB is bound to spread further and as a consequence many more new farmers' varieties will emerge. Also, it is probable that, as for formal sector varieties, the lifetime of such farmers' varieties may be limited, and they might be constantly replaced. Some of farmers' rice varieties in the Philippines have indeed already undergone this process.

\section{GENETIC BACKGROUND OF MODERN FARMERS' VARIETIES}

Most of the new farmers' varieties in the rice-based farming systems of SouthEast Asia are produced in high-input and market-oriented production systems. At first sight, this might seem contrary to expectations, since both public and private sector breeding efforts target such production systems, and not marginalised farming systems. However, the ability to meet immediate livelihood needs and the exposure to both formal sector and local varieties, as is currently the case in many high-input production systems, might provide sufficient flexibility and interest to experiment with available genetic resources and to develop agronomically, culturally and/or economically better adapted varieties.

Broadly speaking, modern farmer varieties can be developed along two lines.

First, they may be simple selections from existing modern cultivars. While some dramatic examples of such varieties are known, we estimate that they represent less than 
10 or 15 percent of rice fields under intensive cultivation. Equal limits should apply to other crops, given the resemblance of farmers' practices and PPB programs across crops.

Second, these varieties may have been produced through participatory plant breeding or independent farmers' selection from segregating materials resulting from conscious or spontaneous crosses. Such varieties, in turn, fall into two categories. The first category contains varieties that are produced from farmers' crosses. Through PPB rice farmers in South-East Asia learn how to perform emasculation, and how to manage F1 and further segregating populations and lines. The community system continues to play an important role in developing these varieties. Once segregating lines are produced by a farmer-breeder, various other farmers may request or take some seeds or panicles to test these in their own farms. These practices continue throughout the seasons so that by the time a new cultivar appears, it is sometimes difficult to identify the original farmer or even the original community. Indeed, such crop development practices fall into traditional farmers' systems of exchange of germplasm. In the past, this did not create problems within such farming communities, given the absence of direct marketing benefits. Major challenges today include how to recognise, "protect," or ensure benefit sharing with all relevant stakeholders, when these new farmer varieties are commercialized by farming communities or third parties. The second category of varieties stemming from PPB contains varieties resulting from selection of segregating materials received from plant breeders. Institutional plant breeders have a comparative advantage in access to germplasm and to facilities for pre-breeding and large-scale production of crosses. This entails that in the near future this category of varieties may become the most important one produced through PPB. Problems regarding access and 
benefit-sharing, as well as protection are more complex for this category, as will be highlighted below.

In short, PPB is a powerful tool that has the potential to greatly improve farmers' plant breeding.

The collective and informal nature of farmers' breeding systems makes it difficult to assign recognition to a single farmer, and even to identify origin of these varieties. Recognition and protection of these varieties, which are the product of collective community efforts, are serious challenges. In addition, accommodation of stringent demands set by some providers of germplasm to farming communities in the framework of PPB projects, also present a difficult problem to solve.

These considerations lead us to a number of questions. In which category of varieties do varieties that farmers select and derive from stable cultivars fall, like the famous "Bordagol" rice variety or the "red IR rice varieties" in Bohol province? Are these varieties "essentially derived?" Since farmers treat all germplasm as raw material, could new Plant Variety Protection laws in fact criminalise traditional practices? Is the only legal option for farmers to make their own crosses in order to make use of the breeder's exemption? If so, this would limit the benefits that small-scale farmers can derive from collaboration with formal sector breeders in the framework of PPB projects.

\section{NEW FARMERS' VARIETIES IN THE IPR ENVIRONMENT}

For many centuries farmers have relied on the free movement of germplasm, in the absence of which traditional agriculture would have collapsed. Free exchange and sharing of landraces among neighbours and relatives, but also within wider circles is 
embedded in farmers' culture. As a consequence the practice to treat all genetic diversity as raw material for direct use and further improvement is still the norm in many parts of the world. This is true, even where farmers have moved from subsistence farming to more intensive and market-oriented production systems, and from maintaining landraces to developing new farmers' varieties. Keeping all germplasm freely available for further use, has allowed farmers to create new types from local as well as from introduced varieties. These varieties, such as "Bordagol," are often exchanged freely and without any financial compensation between users and the communities or the farmers who developed these varieties.

The introduction of systems of intellectual property rights and other rights to plant varieties and genetic resources in developing countries may affect this tradition.

A number of concerns regard future availability and the implementation and consequences of recognition mechanisms. Some major questions in this regard are:

1. whether all genetic material will remain freely available for further (participatory) breeding or whether a selection of such material, in particular varieties developed in public or private breeding programmes or materials that contain specific patented genes, will become unavailable;

2. how such private intellectual property rights relate to the collective nature of farmers' plant breeding; whether and how the role of farmers in developing new varieties can be recognized; and whether the development of farmers' varieties can be stimulated by assigning certain rights to these farmers. All this regardless of whether or not such legal protection would resemble the protection offered to professional breeders in the public and private sector.

Today, the issue of continued availability of parent materials is highly topical. The first reason is that the principles and practices of intellectual protection in general, 
and of plant material in particular, are spreading rapidly among developing countries.

This is due to the implementation of the Agreement on Trade Related Aspects of Intellectual Property Rights (TRIPS), and to a new round of USA-led bilateral trade agreements aimed at strengthening initially introduced protection systems. Second, it is timely because of current efforts at the international level to tighten legislation on plant breeders' rights, as already apparent from the latest version of UPOV (UPOV Act 1991). As a consequence, restrictions may increasingly apply to the availability of parent materials for farmers' breeding and selection.

\section{THE IMPACT OF UPOV}

The designers of UPOV, a sui generis system for the protection of plant varieties, developed a rights system that offers the breeder protection in the market. ${ }^{8}$ However, in this context it formulates two important principles: the right of anybody to use germplasm, including protected materials, for further breeding without any rights accruing to the "owner" of the varieties used. In UPOV terms, this right is called the breeder's exemption, and is absent from most industrial patent systems world-wide. The second principle is the right of farmers to reproduce any materials, including those of protected varieties for their own and non-commercial use without requiring permission from the right holder (and without paying royalties). This right is called the farmer's privilege. Both principles reflect global practices in farmers' culture of sharing and exchanging germplasm. During the 1980s, pressure mounted to tighten the conditions

\footnotetext{
8 The UPOV (International Union for the Protection of New Varieties of Plants) convention is an international agreement on the principles and conditions for plant breeder's rights. As such it is the major sui generis intellectual property right system in the field of plant breeding. According to the WTO TRIPS agreement, countries are obliged to adopt a patent system or a sui generis system to allow for the protection of the products of plant breeding.
} 
under which the breeder's exemption and the farmer's privilege are valid. Reasons put forward to restrict application of these rules have guided the revision of UPOV, in the UPOV Convention of 1991. The latest version states that in order to avoid "cosmetic breeding' the breeder's exemption no longer applies in the case of so-called essentially derived varieties. These are very similar to original varieties, and show minor differences that are the result of particular 'acts of derivation' requiring modest efforts, such as mutation, repeated backcrossing and insertion of genes through biotechnological means. Such essentially derived varieties fall within the scope of protection of the original variety that provided the basis for the new one, and can only be protected in consultation with the rightholder of the original variety. The implementation of the concept of essential derivation ${ }^{9}$ is still under debate, especially among the seed industry partners. In addition, it is asserted that the 'farmers' privilege' has to be restricted to provide a breeder sufficient possibilities to claim his rewards. In some industrialized countries for particular crops, the right to re-use seeds or planting materials on a farm has been restricted. This was introduced in order to avoid situations in which for example commercial flower growers can buy a few branches of a new rose or carnation variety and quickly multiply the stock to cover a large commercial flower production area on their farms. In addition, in many countries free exchange of field crop seeds has been restricted, because commercial farmers started selling large quantities of seed to their neighbours (without branding, thus officially outside commercial seed marketing channels) and breeders lost significant sources of income.

\footnotetext{
${ }^{9}$ A variety is considered "essentially derived" from another variety when it is predominantly derived from the initial variety by selection in a population (being a protected variety), by selection of a mutant or a somaclonal variant, by repeated backcrossing or by transformation though genetic engineering. The new variety must be distinguishable from the initial variety, and except for the differences which result from the act of derivation, conform to the essential characteristics of the initial variety.
} 
These exceptions to the important principles of breeder's exemption and farmers' privilege are becoming the general rule. Exchange of seed of protected varieties is now formally outlawed in modern UPOV-compatible Plant Variety Protection (PVP) laws, regardless of crop, and in UPOV-circles a debate is underway to restrict the breeder's exemption further. The wide application of such restrictions on the principles of breeder's exemption and farmer's privilege renders these PVP systems less compatible with farmers' traditions and current farmers' practices.

For example, mutant varieties selected by farmers like "Bordagol" are technically 'essentially derived'. Whether they are also essentially derived in a legal sense depends on the protection status of the original variety. Since IR36 was never protected by plant breeder's rights, "Bordagol" is not 'essentially derived' from a legal perspective. However, as public and international research institutions are starting to protect their varieties, this situation might change and farmers may produce essentially derived varieties that are based on parent lines that are legally protected. This would mean that the spread from farmer to farmer of varieties like "Bordagol" would require the approval of the original breeder. Obviously, such approval might be hard to obtain for small-scale farmers, and in reality others might attempt to obtain the legal protection as an essentially derived variety. Moreover, it would be very difficult for the original rightholder to police the spread of such essentially derived varieties.

Regarding the farmers' privilege, it would outlaw the exchange or selling of seed within communities. A Material Transfer Agreement such as the one used by PhilRice discussed below would even outlaw the selling of seed of farmers' selections from 
segregating lines, and in fact function as a disincentive for farmers' breeding activities.

Again, such practices will be very difficult to monitor.

\section{THE IMPACT OF PATENT SYSTEMS}

In addition to the impact of tightening of plant variety protection systems, soon the patent system will also considerably affect farmers' seed practices, in particular farmers' access to seed. The patent system is not rooted in agriculture, and does not include the breeder's exemption and the farmer's privilege principles. Patents can apply to germplasm in several forms. In a few countries, most notably in the USA, a plant and its seed, or even a characteristic of the plant, can be patented as long as it is new, innovative and in some way useful. This results in the possibility that entire groups of varieties may fall under a single patent. However, it is more common that part of a plant is patentable (e.g. a gene whose function in the plant is known) or that the process by which a plant is generated falls within the scope of protection (e.g. a method to introduce a gene by biotechnological means). In this way, patent law is introducing new private ownership rights over germplasm and forbidding its use in farmers' breeding activities in more and more countries.

This may be illustrated by the introduction of cotton varieties containing genes of Bacillus thuringiensis (Bt), which protects the crop against its major pests, the Heliothis complex. Farmer-breeders and local commercial breeders in India quickly introduced the pest resistance in a number of locally adapted varieties once these transgenic varieties were introduced in the country. In reaction, the patent holder quickly took action to protect its market potential. Since the patent had not been approved in India, the company used other laws (especially biosafety laws) existing in the country to 
successfully control farmers' use. This example illustrates that some breeding companies will attempt to protect their varieties, through intellectual property rights or through any other existing legislation, from unwanted use by small-scale farmers.

\section{THE IMPACT OF ACCESS AND BENEFIT-SHARING REQUIREMENTS}

Countries that have ratified the Convention on Biological Diversity (CBD) are bound to facilitate the access to genetic resources. However, this may require Prior Informed Consent from the source country, as well as benefit sharing arrangements. Whereas these conditions apply primarily to cross-border exchanges of genetic resources, some countries (e.g. Uganda) also use it to regulate the acquisition and subsequent use of germplasm within the country. As a consequence, access and benefit sharing regulations required by CBD may also limit the availability and free use of germplasm in farmers' breeding activities.

The current initial agreement between the PEDIGREA project and the National Institute for Rice Research of Indonesia is that NGOs and farmers' associations involved will ensure recognition of the origin of the lines used in their PPB projects. However, the tradition of free movement of germplasm to some extent hampers implementation of this agreement. Only in some cases it is possible to persuade farmers to assign origin and to monitor the development of these lines. In other cases, farmers simply consider this irrelevant or do not recognise the principles underlying such ownership and origin. When these lines diffuse into wider areas and reach a greater number of farmers, back-tracking may require major efforts. This problem is evident in the case of the agreement between PEDIGREA and the Philippine National Rice Research Institute, which was formalized through a Material Transfer Agreement (MTA). First, this MTA states that the material 
shall not be used for any profit or commercial purposes and acknowledges that PHILRICE holds ownership of the material. With respect to advanced breeding lines (F6 and higher) this limits the use of further selections from this material to subsistence at the community level. Second, the MTA considers a new variety as not essentially derived only if 25 percent or more of its lineage is different from the provided lines. This allows for the use of the material in farmer cross-breeding, provided it is not followed by backcrossing to the provided material. Obviously, the means for farmers to monitor the genetic background of their selected lines are extremely limited, if not absent. Finally, the recipient (the PEDIGREA partner PPRDI) is not allowed to transfer the material to third parties. However, when the material is used in the project, unregulated diffusion is difficult to prevent. This MTA, although not originally developed to cover transfer of materials to farmers' communities, was nevertheless applied to transfer in the PEDIGREA project. This example clearly shows some of the problems still to be solved if farmers' breeding efforts are to be recognized and facilitated.

\section{THE COLLECTIVE NATURE OF FARMERS' BREEDING}

At the community level, we often find that few farmers perform crosses; more farmers are able to manage early segregating populations (whether obtained from farmer crosses or from institutional breeders); and many more farmers are interested in selecting from more advanced lines or between stable varieties. Thus, the farmer-breeders of the first two categories provide material to their communities, and often need the involvement of their fellow farmers since they do not possess sufficient land and time to manage the trials on their own farm. Once distributed, materials are monitored and inspected by the farmer-breeders and interesting lines might be returned to them for 
follow-up experimentation. This, again, shows that farmers' breeding activities are often a collective effort, and participatory breeding programmes by definition involve different actors sharing tasks. How deeply this collective nature is engrained in farmers' culture is illustrated in the following citation of Brush (1998, p. 761):

"The lack of possessive individualism among peasant farmers regarding seeds and genetic resources might be seen as an adaptive cultural trait in the face of the risks in agriculture and the importance of diversity in meeting those risks. The efficacy of peasant seed systems is the fact that particularly good cultivars spread rapidly and over a wide area."

Although individual recognition is not entirely taboo in farmers' systems, as some varieties are directly attributed to specific individuals, the general rule is that farmers regard their breeding and selection efforts as a collective rather than an individual exercise. However, the highly collective and informal nature of the farmers' breeding efforts is not recognized in intellectual property rights systems. Assigning individual recognition, as under plant breeder's rights and patent right systems, to an essentially collective system of plant breeding is inconsistent with farmers' breeding systems, and in practice such systems cannot be easily applied to farmers' varieties.

Current IPR systems have limited possibilities for joint application of protection. Joint application by a number of inventors may provide equal rights to all inventors who are listed in the application. But listing all participants of a participatory breeding scheme would stifle the actual implementation of the resulting rights, since all actions would require the full approval of all rightholders. In other words, such jointly held 
rights will be difficult to implement, the more so if rights are to be shared among farmers in the community, scientists and collaborators in the PPB programme.

An alternative option may be to bring the rights under the responsibility of a farmers' cooperative or other legal entity that represents the different stakeholders. Such an entity may take the necessary decisions on behalf of its members and may enter into contractual relations with breeders, research institutes and users. Such an option, however, requires registered membership and does not easily fit in concepts of community membership that are often implicit (e.g. by birth).

Thus, although IPR grant private rights, these can also be exercised by groups as long as they are formally registered. However, this does not resolve the fact that current plant variety protection laws require levels of distinctness, uniformity and stability, which are often not met by farmers' varieties. Neither does it take into account that many farmer-bred varieties are unlikely to capture a significant share in the commercial seed market. When a variety occasionally does, it may be very difficult for the community to monitor and act against infringements on their plant breeder's rights. Most importantly, all such options probably underestimate the likelihood that communities might not recognize individual rights over germplasm and might not wish to exercise community rights against neighbouring communities. Assigning ownership for economic or financial returns runs against farmers' spirit of free exchange. More than the legal problems that would result from attempts to bring farmers' varieties under current intellectual property rights systems, these cultural motives will probably prevent the application of such IPR systems on farmers' varieties. Adapting current PVP and patent systems to incorporate the protection of farmers' collective breeding efforts is therefore not an advisable 
approach, and protection of the efforts of farmers' breeding will have to be reached by other means.

\section{FARMERS' VARIETIES AND PLANT BREEDER'S RIGHTS REQUIREMENTS}

Distinctness, uniformity and stability are characteristics required to obtain property right protection according to the UPOV convention. Like landraces and modern cultivars, modern farmers' varieties are usually distinct (Bertuso et al., 2005; Tin et al., 2001). High-input systems and the urban market require a higher degree of uniformity and the involved agro-ecosystems provide more reliable growing conditions than marginal ecosystems. As a consequence these modern farmers' varieties are also more uniform than landraces. Nevertheless, many of these varieties are still composed of a number of genotypes and generally would need further selection to conform to the definitions of uniformity under plant breeder's rights, in particular according to the UPOV Convention. For small and resource poor farmers, greater uniformity could constitute higher risk and run counter to their interests. Therefore, experience has shown that these varieties are not normally subjected to selection for uniformity to the same extent as modern formal sector cultivars. The lower degree of uniformity also means that new farmers' varieties are less stable over generations than required under the UPOV interpretation. Different types within a farmers' variety may be favoured over time under given growing conditions, and over the course of seasons biological or abiotic stresses might shift the balance between the genotypes constituting the variety.

Summarizing, new farmer varieties are more distinct, uniform and stable than the remaining landraces dominant in low-input marginalised farming systems, but often less than modern varieties distributed by the formal system. 
The high level of uniformity and stability of formal sector varieties is not an agronomic advantage per se. It results from the economic demand for uniformity by increasingly large retailer chains, and from the need of breeding companies to legally protect the varieties stemming from their breeding programs. It is technically possible to relax the uniformity requirements and to use norms applied for cross-fertilizing crops to describe new farmers' varieties. However, breeders may regard this as a disadvantage for at least two reasons. First, the genetically wider claims will be more difficult to enforce since the possibility to distinguish varieties from each other will decrease. Second, this opens ways for strategic protection leading to the monopolization of entire genepools. On the other hand, these needs and concerns are of no relevance to small-scale farmers.

\section{PROTECTING FARMERS' VARIETIES}

The products of breeding from the public or private sector have become easily available, but their development is often long and labour-intensive. As a consequence, especially private but increasingly also public sector products, are protected against misappropriation and free-riding. Such protection does not apply to modern farmer varieties, or to landraces. But do modern farmers' varieties need protection against misappropriation? And how can new farmers' varieties be protected?

Misappropriation may not only mean that third parties might market farmers' breeding products, thus potentially damaging farmers' market prospects, but also that they might claim and obtain plant breeders' rights or patent rights, resulting in the denial of market access of the communities from which such varieties have originated. This kind of misappropriation - a few cases have been reported - is undesirable and calls for forms of protection of landraces and farmer varieties alike. 
The question then becomes whether plant breeder's rights according to the UPOV Convention provide appropriate protection for farmer varieties, given (1) the usually lower level of distinctness, uniformity and stability, (2) the notion that farmers' varieties are often the product of community efforts, (3) and that farmer varieties (not landraces) include genetic information from the introgression of public and private sector germplasm.

Based on these concerns, we suggest that farmers' varieties need protection against appropriation. For both farmers' varieties and landraces, a call for protection recognises farmers' contributions to current crop diversity and the need to support those farmers' systems which maintain diversity and develop local varieties for future use. Farmers' contributions to develop and manage diversity are recognized in the Convention on Biological Diversity (Art. 8j; referred to below as CBD) and the International Treaty on Plant Genetic Resources for Food and Agriculture (Art. 9; referred to below as IT PGRFA). Still, it is arguable whether the CBD, IT PGRFA, or UPOV currently provide the mechanisms to support farmers' breeding systems. The next section suggests options for alternative protection mechanisms.

\section{ALTERNATIVE OPTIONS FOR THE PROTECTION OF THE PRODUCTS OF FARMERS' BREEDING}

A host of publications has addressed the impact of strengthened intellectual property rights systems and strengthened CBD-based national sovereignty legislation on farmers' practices (RAFI 1998; Correa 1999; Crucible II Group, 2000; GRAIN, 2004; Safrin 2005). In general, these publications provide a clear analysis, but alternative options have only been poorly elaborated. This chapter is an attempt to contribute to 
some of the concepts developed earlier, starting from the conviction that currently used intellectual property rights systems are not appropriate to recognize and protect new farmers' varieties.

Alternative and collective rights systems may exist in other domains, or they may need to be newly developed. Two basic justifications can guide the identification or development of protective measures. The first one stems from the recognition of farmers' contribution to the development and management of genetic resources over the ages. The use of farmers' varieties must be promoted, but only with the approval and involvement of the original developers of such varieties and the communities concerned. This implies recognition and reward for the development of new farmers' varieties contributing to the further development of genetic resources. Recognition and reward may also contribute to self-esteem. The second justification recognizes the concern that misappropriation of newly developed farmers' varieties (as well as landraces for that matter) should be prevented. This justification refers to protection in a narrow sense and is defensive in nature. A discussion on alternative protection measures should also take into account the potential decrease in access by farmers to part of the available germplasm due to the new international regulatory environment.

In this context it should be noted that nothing in the relevant international agreements, including the WTO TRIPs Agreement, prevents countries from establishing other forms of intellectual property rights protection or from expanding the concept of plant varieties that may be protected under breeder's rights, or from establishing new forms of protection (Correa 1999). 
In taking worldwide farmers' culture as a reference we wish to elaborate on the earlier suggestions by Correa (1999). He proposed that protection should not be based on an exclusive right and only grant the right to prevent material of actual or potential commercial value from being acquired, used or disclosed by others in a manner that is harmful to the livelihood of the communities in which the varieties were developed. The author also stressed that adequate protection requires a clear definition of the subject matter, broad enough to cover alteration and improvement, and recognition of the informal, collective and cumulative systems of innovation of communities. Though many elements of such a regime would be determined at the national level, its recognition at the international level would be necessary to ensure its effectiveness.

The Crucible Group II (2000) not only reiterated this position by stating that the purpose of alternative rights systems includes providing legal recognition for varieties that can not be protected under existing patent and/or plant breeder's rights laws, thereby recognizing the value of farmers' plant variety innovations, but also providing a means of sharing the benefits derived from the use of farmers' or traditional varieties as breeding material and/or for commercial purposes, and encouraging innovative plant breeding.

We have argued that in searching for alternative protective measures the concept of intellectual property rights is no longer suitable. What is needed is an alternative rights system that does not focus on property, but on recognition and protection. Therefore, we have built on alternative systems, which are already available, and propose the term "origin recognition rights" for such a system, that may be composed of multiple measures. Both the principle of declaration of origin and farmers' registers may be part of 
this system, whereas current seed legislation may need adaptations to make the system operational.

\section{DECLARATION OF ORIGIN}

The recognition of farmers' contributions might borrow from laws that offer protection to the producer. Legislation for the protection of producers exists in national laws in a number of countries, in particular in the form of protection of brand names which have a geographical basis. In the recent international debate, a requirement for declaration of origin has often been proposed, but rather to strengthen national sovereignty than as a recognition of farmers' rights. Nevertheless, the principle of declaration of origin may well be applied for the latter purpose.

A geographical indication is a label used on goods that have a specific geographical origin and possess qualities or a reputation linked to the place of origin. Most commonly, a geographical indication consists of the name of the locality of origin of the good. Geographical indications are protected in accordance with national laws under a wide range of concepts, such as laws against unfair competition, consumer protection laws, laws for the protection of certification marks or special laws for the protection of geographical indications or appellations of origin. In essence, unauthorized parties may not use geographical indications if such use is likely to mislead the public as to the true origin of the product (WIPO, 2005).

The concept of geographical indication is clearly different from that of trademarks, and more appropriate to protect farmers' varieties. Trademarks are used to distinguish goods and services, and gives an enterprise the right to exclude others from using the trademark. A geographical indication refers to a certain locality and to certain 
characteristics of the locality of production. It may be used by all producers who make their products in the designated place, and whose products share typical qualities. A number of treaties provide for the protection of geographical indications, most notably the Paris Convention for the Protection of Industrial Property of 1883, and the Lisbon Agreement for the Protection of Appellations of Origin and Their International Registration, as well as WTO TRIPs (Articles 22 to 24).

The European Union has adopted legislation based on earlier national laws that recognise the origin of specific agricultural products, such as wine and cheese. Similar legislation has been adopted in other countries. This legislation offers protection to the producers of the community or other entity of origin, since the products concerned may only be produced and marketed under the name of and with reference to the region of origin. But it also offers a guarantee for the consumer, who can be assured that the product originates from that region. Although this type of legislation concerns agricultural products, it could guide the development of legislation on farmers' varieties. In fact, implementation of EU Directive 98/95/EC foresees the introduction in the European Union of the concept of "conservation varieties," which includes a declaration of the geographic origin or of the region of adaptation. Farmers' varieties, products and seeds, could be protected under such legislation, recognising farmers of a specific region as the developers of a variety stemming from that region, and reserving the right to market the variety under that name to farmers from that region. The red rice varieties of Bohol might be marketed as Bohol Red Paddy, in line with the practice of farmers to often name a variety after its area of origin. Such approach would not result in ownership over genetic resources, but would only grant collective ownership over the declaration of 
origin. It would give farmers of the region of origin an edge over farmers from other regions without preventing other farmers to use and market these genetic resources. The approach would neither monetize genetic resources nor discourage farmers to share these resources, but recognise their contributions as developers. The major difference with existing legislation on geographical indication is that by applying the concept to farmers' varieties it would further strengthen the cultural component (the ability to create new and typical diversity) in addition to a physical component (the place of origin). Such cultural component is already included in existing legislation, since for agricultural products it is often the place of origin as well as the skills to produce a certain good in that environment that is recognized and protected.

If marketing under such systems were reserved to small-scale farmers ${ }^{10}$, the economic consequences on farmer's privilege and the breeder's exemption would be small. In order to promote further development of plant genetic resources, any restrictive principles under UPOV may be avoided for this category of users, i.e. for farmers who make use of UPOV-protected varieties to develop their own farmers' varieties. Most likely, the breeder's exemption of UPOV-based legislation should offer such option already. If in future, such farmers' varieties would encompass genes introduced through genetic modification, an exemption from patent rights-based restrictions for the use by small-scale farmers might be promoted as well.

\footnotetext{
${ }^{10}$ Although here the term small-scale farmer is used in a general sense, in a law such term would have to be defined. A legal definition of small-scale farmer might be based on acreage, income or marketed seed volume.
} 


\section{FARMERS' REGISTERS}

A national register of farmers' varieties containing name and origin as well as essential descriptors of the variety could be a central element of a system of origin recognition. The Crucible Group II (2000) suggests that a variety may be identifiable if, with respect to the characteristics of its plants or with respect to a given distribution of characteristics among plants, it can be identified by a person skilled in the art, and suggests that this interpretation of distinctness and identification may allow for protection of farmers' varieties, replacing the UPOV requirements for distinctness, uniformity and stability, by the principle of identifiability.

The current international legal environment may not yet be able to exclude misappropriation: the protection of a plant variety by a party that has not developed that variety without consent of the original developer. Implementation of the IT PGRFA and of the Bonn Guidelines under the CBD, and adaptation of legislation to document the origin of germplasm used in breeding programmes and protected by IPR, should protect new farmers' varieties from misappropriation, and guarantee their continued availability in the public domain. A national register enlisting the characteristics of farmers' varieties as well as associated knowledge can provide a formal way to prevent misappropriation through plant breeder's rights or patents by third parties. It provides evidence of prior existence as well as origin.

However, it can be questioned if such legislation could also be regarded as a sufficient guarantee to the consumer. This will depend on the capacity to monitor and control the identity of seeds marketed by farmers. 


\section{A REVISION OF SEED LAWS}

There is general agreement that a national seed regulatory regime should respond to economic, political and technological factors specific to the particular country, but there is considerable controversy regarding the direction of regulatory reform (Tripp, 2002). In practice, seed laws often form a barrier to the marketing of farmers' varieties. In this context we have argued that seed laws might have to be adapted to allow for the marketing of farmers' varieties that do not fulfil the criteria of distinctness, uniformity and stability as generally defined under UPOV-type legislation, but that do fulfil the criteria of identifiability. Extension of the clause on essentially derived varieties beyond protected varieties, including all varieties registered through plant breeder's rights or through listing in farmers' registers, may then prevent unfair competition by seed companies or public institutions against farmers, in case the public or private sector attempt to market new farmers' varieties.

At the very least, seed policies should not be detrimental to efforts to maintain and create crop genetic diversity on-farm. But even more important is that seed policies should encompass measures safeguarding and promoting the maintenance and development of genetic diversity on-farm, thus contributing to food sovereignty, to farmers' livelihood, and to a more sustainable agriculture (Visser, 2002). 


\section{CONCLUSION}

The global community, through the Convention on Biological Diversity and the International Treaty on Plant Genetic Resources for Food and Agriculture, has recognised the contribution of farmers to the maintenance of genetic resources. Under current conditions, this contribution will increasingly include the development of new farmers' varieties. Such varieties need recognition and protection. Current intellectual property rights do not protect farmers developing their own varieties, on the contrary they are a threat to this practice. Therefore, current intellectual property right legislation needs reinterpretatio, and new forms of protection should be introduced to facilitate the continuing contribution of farmers to the maintenance of genetic diversity. Modern farmers' varieties may derive from public or private plant varieties, and legislation should be adapted to allow this practice, which is not damaging the market position of the products of professional breeding. In this paper we have suggested some options for such protection, taking into account the growing share of modern farmers' varieties in locally maintained germplasm. These suggestions build on the notion that farmers' practices of free exchange of genetic resources are culturally based, and that these cultures do not regard genetic resources as sources of economic reward.

It is important to mention that the above suggestions can have various unforeseen consequences and therefore these need careful consideration (Boisvert, 2003). Discussion should focus on the relevant subject material, which will increasingly be new farmers' varieties rather than landraces. 


\section{REFERENCES}

Bertuso, A.R.,R. van Treuren, F.A.van Eeuwijk and B. Visser. 2005. Characterisation of red rice Oryza sativa varieties developed under on-farm dynamic management on Bohol, Philippines. FAO/IPGRI Plant Genetic Resources Newsletter 142: 1-5.

Boisvert, V. 2003. From the conservation of genetic diversity to the promotion of quality foodstuff: Can the French model of 'Appellation d'Origine Contrôlée' be exported? Paper presented at the CAPRi Workshop on property rights, collective action and conservation of local genetic resources, Rome, September 29 -October 2 .

Brush, S.B. 1998. Bio-cooperation and the Benefits of Crop Genetic Resources: the Case of Mexican Maize. World Development 26 (5): 755-766.

Brush, S.B. 1999. The issues of in situ conservation of crop genetic resources. In Genes in the field: On-farm conservation of crop diversity, ed. S.B. Brush. Boca Raton, USA: Lewis Publishers.

Ceccarelli, S., S. Grando, E. Bailey, A. Amri, M. El-Felah, F. Nassif, F., S. Rezgui and A. Yahyaoui. 2001. Farmer participation in barley breeding in Syria, Morocco and Tunisia. Euphytica 122 3, $521-536$.

Conserve. 2001. Assessment of lowland rice varieties distributed by Conserve in Arakan Valley Complex, Cotabato, Philipines. Conserve Handbook 2. Manila, Philippines: Searice.

Correa, C. M. 1999. In situ conservation and intellectual property rights. In Genes in the field: On-farm conservation of crop diversity, ed. S.B. Brush. Boca Raton, USA: Lewis Publishers.

Crucible II Group 2000. Seeding solutions. Volumes 1 and 2. Ottawa: IDRC.

FAO. 1998. The state of the world's plant genetic resources for food and agriculture. Rome: FAO.

GRAIN. 2004. Freedom from IPR: towards a convergence of movements. Seedling October, 1-4.

Joshi, K.D., B.R. Sthapit, and J.R.Witcombe. 2001. How narrowly adapted are the products of decentralised breeding? The spread of rice varieties from a participatory plant breeding programme in Nepal. Euphytica 122 (3): 589 - 697.

Louette, D. 1999. Traditional management of seed and genetic diversity: what is a landrace? In Genes in the field: On-farm conservation of crop diversity, ed. S.B. Brush. Boca Raton, USA: Lewis Publishers.

RAFI. 1998. Enclosures of the mind: Intellectual monopolies. Ottawa: RAFI. 
Safrin, S. 2005. Hyperownership in a time of biotechnological promise: the international conflict to control the building of blocks of life. Amer. J. Internat. Law 98: 641 685.

Sperling, L., Ashby, J.A., Smith, M.E., Weltzien, E. \& McGuire, S. 2001. A framework for analyzing participatory plant breeding approaches and results. Euphytica 122 $3,439-450$.

Tin, H.Q., Berg, T. \& Bjørnstad, Å. 2001. Diversity and adaptation in rice varieties under static ex situ and dynamic in situ management. Euphytica 122 (3): 491 - 502.

Tin H.Q., N.N. De, R. van Treuren, and B.Visser. Analysis of spatial and temporal variation of the farmer's ruice variety Tainguyen under changing cropping systems in the Mekong Delta, Vietnam. Submitted for publication.

Toledo Machado, A. and M.S. Fernandes. 2001. Participatory maize breeding for low nitrogen tolerance. Euphytica 122 (3): 567 - 573.

Tripp, R. 2002. Seed regulatory reform: an overview. In Seed policy, legislation and law, ed. N.P. Louwaars. New York: Haworth Press, Inc.

Visser, B. 2002. An agrobiodiversity perspective on seed policies. In Seed policy, legislation and law, ed. N.P. Louwaars. New York: Haworth Press, Inc.

WIPO. 2005. Geographical indications? http://www.wipo.int/aboutip/en/geographical_ind.html, version July 2005. 
List of CAPRi Working Papers

01 Property Rights, Collective Action and Technologies for Natural Resource Management: A Conceptual Framework, by Anna Knox, Ruth Meinzen-Dick, and Peter Hazell, October 1998.

02 Assessing the Relationships between Property Rights and Technology Adoption in Smallholder Agriculture: A Review of Issues and Empirical Methods, by Frank Place and Brent Swallow, April 2000.

03 Impact of Land Tenure and Socioeconomic Factors on Mountain Terrace Maintenance in Yemen, by A. Aw-Hassan, M. Alsanabani and A. Bamatraf, July 2000 .

04 Land Tenurial Systems and the Adoption of a Mucuna Planted Fallow in the Derived Savannas of West Africa, by Victor M. Manyong and Victorin A. Houndékon, July 2000.

05 Collective Action in Space: Assessing How Collective Action Varies Across an African Landscape, by Brent M. Swallow, Justine Wangila, Woudyalew Mulatu, Onyango Okello, and Nancy McCarthy, July 2000.

06 Land Tenure and the Adoption of Agricultural Technology in Haiti, by Glenn R. Smucker, T. Anderson White, and Michael Bannister, October 2000.

07 Collective Action in Ant Control, by Helle Munk Ravnborg, Ana Milena de la Cruz, María Del Pilar Guerrero, and Olaf Westermann, October 2000.

08 CAPRi Technical Workshop on Watershed Management Institutions: A Summary Paper, by Anna Knox and Subodh Gupta, October 2000.

09 The Role of Tenure in the Management of Trees at the Community Level: Theoretical and Empirical Analyses from Uganda and Malawi, by Frank Place and Keijiro Otsuka November 2000.

10 Collective Action and the Intensification of Cattle-Feeding Techniques a Village Case Study in Kenya's Coast Province, by Kimberly Swallow, November 2000.

11 Collective Action, Property Rights, and Devolution of Natural Resource Management: Exchange of Knowledge and Implications for Policy, by Anna Knox and Ruth Meinzen-Dick, January 2001. 
12 Land Dispute Resolution in Mozambique: Evidence and Institutions of Agroforestry Technology Adoption, by John Unruh, January 2001.

13 Between Market Failure, Policy Failure, and "Community Failure": Property Rights, Crop-Livestock Conflicts and the Adoption of Sustainable Land Use Practices in the Dry Area of Sri Lanka, by Regina Birner and Hasantha Gunaweera, March 2001.

14 Land Inheritance and Schooling in Matrilineal Societies: Evidence from Sumatra, by Agnes Quisumbing and Keijuro Otsuka, May 2001.

15 Tribes, State, and Technology Adoption in Arid Land Management, Syria, by Rae, J, Arab, G., Nordblom, T., Jani, K., and Gintzburger, G., June 2001.

16 The Effects of Scales, Flows, and Filters on Property Rights and Collective Action in Watershed Management, by Brent M. Swallow, Dennis P. Garrity, and Meine van Noordwijk, July 2001.

17 Evaluating Watershed Management Projects, by John Kerr and Kimberly Chung, August 2001.

18 Rethinking Rehabilitation: Socio-Ecology of Tanks and Water Harvesting in Rajasthan, North-West India, by Tushaar Shah and K.V.Raju, September 2001.

19 User Participation in Watershed Management and Research, by Nancy Johnson, Helle Munk Ravnborg, Olaf Westermann, and Kirsten Probst, September 2001.

20 Collective Action for Water Harvesting Irrigation in the Lerman-Chapala Basin, Mexico, by Christopher A. Scott and Paul Silva-Ochoa, October 2001.

21 Land Redistribution, Tenure Insecurity, and Intensity of Production: A Study of Farm Households in Southern Ethiopia, by Stein Holden and Hailu Yohannes, October 2001.

22 Legal Pluralism and Dynamic Property Rights, by Ruth Meinzen-Dick and Rajendra Pradhan, January 2002.

23 International Conference on Policy and Institutional Options for the Management of Rangelands in Dry Areas, by Tidiane Ngaido, Nancy McCarthy, and Monica Di Gregorio, January 2002. 
24 Climatic Variablity and Cooperation in Rangeland Management: A Case Study From Niger, by Nancy McCarthy and Jean-Paul Vanderlinden, September 2002.

25 Assessing the Factors Underlying the Differences in Group Performance: Methodological Issues and Empirical Findings from the Highlands of Central Kenya, by Frank Place, Gatarwa Kariuki, Justine Wangila, Patti Kristjanson, Adolf Makauki, and Jessica Ndubi, November 2002.

26 The Importance of Social Capital in Colombian Rural Agro-Enterprises, by Nancy Johnson, Ruth Suarez, and Mark Lundy, November 2002.

27 Cooperation, Collective Action and Natural Resources Management in Burkina Faso: A Methodological Note, by Nancy McCarthy, Céline Dutilly-Diané, and Boureima Drabo, December 2002.

28 Understanding, Measuring and Utilizing Social Capital: Clarifying Concepts and Presenting a Field Application from India, by Anirudh Krishna, January 2003.

29 In Pursuit Of Comparable Concepts and Data, about Collective Action, by Amy Poteete And Elinor Ostrom, March 2003.

30 Methods of Consensus Building for Community Based Fisheries Management in Bangladesh and the Mekong Delta, by Parvin Sultana and Paul Thompson, May 2003.

31 Formal and Informal Systems in Support of Farmer Management of Agrobiodiversity: Some Policy Challenges to Consolidate Lessons Learned, by Marie Byström, March 2004.

32 What Do People Bring Into the Game: Experiments in the Field About Cooperation in the Commons, by Juan-Camilo Cárdenas and Elinor Ostrom, June 2004.

33 Methods for Studying Collective Action in Rural Development, by Ruth Meinzen-Dick, Monica Di Gregorio, and Nancy McCarthy, July 2004.

34 The Relationship between Collective Action and Intensification of Livestock Production: The Case of Northeastern Burkina Faso, by Nancy McCarthy, August 2004. 
35 The Transformation of Property Rights in Kenya's Maasailand: Triggers and Motivations by Esther Mwangi, January 2005.

36 Farmers' Rights and Protection of Traditional Agricultural Knowledge, by Stephen B. Brush, January 2005.

37 Between Conservationism, Eco-Populism and Developmentalism - Discourses in Biodiversity Policy in Thailand and Indonesia, by Heidi Wittmer and Regina Birner, January 2005.

38 Collective Action for the Conservation of On-Farm Genetic Diversity in a Center of Crop Diversity: An Assessment of the Role of Traditional Farmers' Networks, by Lone B. Badstue, Mauricio R. Bellon, Julien Berthaud, Alejandro Ramírez, Dagoberto Flores, Xóchitl Juárez, and Fabiola Ramírez, May 2005.

39 Institutional Innovations Towards Gender Equity in Agrobiodiversity Management: Collective Action in Kerala, South India, by Martina Aruna Padmanabhan, June 2005.

40 The Voracious Appetites of Public versus Private Property: A View of Intellectual Property and Biodiversity from Legal Pluralism, by Melanie G. Wiber, July 2005.

41 Who Knows, Who Cares? Determinants of Enactment, Awareness and Compliance with Community Natural Resource Management Bylaws in Uganda, by Ephraim Nkonya, John Pender, Edward Kato, Samuel Mugarura, and James Muwonge, August 2005.

42 Localizing Demand and Supply of Environmental Services: Interactions with Property Rights, Collective Action and the Welfare of the Poor, by Brent Swallow, Ruth Meinzen-Dick, and Meine von Noordjwik, September 2005.

43 Initiatives for Rural Development through Collective Action: The Case of Household Participation in Group Activities in the Highlands of Central Kenya, By Gatarwa Kariuki and Frank Place, September 2005.

44 Are There Customary Rights to Plants? An Inquiry among the Baganda (Uganda), with Special Attention to Gender, by Patricia L. Howard and Gorettie Nabanoga, October 2005. 